\title{
VERSITA
}

\section{DEPENDENCE OF DOUGLAS-FIR MEAN HEIGHT ON GEOGRAPHIC ORIGIN OF CANADIAN PROVENANCES IN SEEDLING NURSERY CONDITIONS}

\author{
VLADAN POPOVIĆ ${ }^{1}$, VERA LAVADINOVIĆ ${ }^{1}$, IVAN BJELANOVIĆ ${ }^{2}$, VUKAN \\ LAVADINOVIĆ ${ }^{2}$
}

${ }^{1}$ Institute of Forestry, Kneza Viseslava No. 3, Belgrade, Serbia; e-mail: veralava@eunet.rs

${ }^{2}$ Faculty of Forestry, Kneza Viseslava No. 3, Belgrade, Serbia

\begin{abstract}
Popović V., Lavadinović V., Bjelanović I., Lavadinović V.: Dependence of Douglas-fir mean height on geographic origin of Canadian provenances in seedlings nursery conditions. Ekológia (Bratislava), Vol. 32, No. 3, p. 328-334, 2013.
\end{abstract}

\begin{abstract}
Seed and seedling tests, performed with the aim of acquiring knowledge about the genetic potential of selected provenances, are generally one of the first trials in a complex system of comparative examinations to be conducted upon the introduction of alien tree species. This paper presents the results of the investigation of the dependence of the mean height of 14 Canadian origin Douglas-fir provenances, originating from latitude $49^{\circ} 10^{\prime}$ to $51^{\circ} 35^{\prime}$, longitude $11^{\circ} 20^{\prime}$ to $120^{\circ} 10^{\prime}$ and the altitude of 488 to $1,070 \mathrm{~m}$, on the geographic origin.

Understanding the variations in the mean height of a seedling is of major importance for acquiring knowledge on genetic potential of selected provenances, which are one of the key parameters for the introduction of Douglas fir into relevant forest sites in Serbia.
\end{abstract}

Key words: Douglas fir, provenance, seedlings, mean height.

\section{Introduction}

The primary reason for the establishment of provenance test is to determine the economic justification for the introduction and to assess the risk arising from transfer of seeds from their natural, autochthonous zones of origin. Introduction must involve only those species that attain maximum production qualities and economic effectiveness in their natural area. Upon the transfer of seeds into forest sites with new ecological conditions, the genetic potential of species is tested by means of provenance trials. Another important reason for the establishment of provenance trials is to avoid risk and damage from the introduction of nonproductive and non-adaptive provenances. Several years-long trials of introduced seed begin by a laboratory analysis of germination, measurement of tray plants, survival percentage of seedling nursery plants, establishment of a field trial and a years-long measurement of plant taxation elements until fruit bearing and collection of F2 generation seeds. 
Douglas fir (Pseudotsuga menziesii Mirb. Franco) is abundant in North America, from west Oregon, across the Washington state, to British Columbia. Autochthonous forests of this type are one of the most productive forests in the world, which is the reason for a considerable interest that exists for establishment of this culture beyond the limits of its natural areal (Bradley et al., 1999). Owing to its extensive adaptability, ecological variations and potential value, Douglas fir is one of the most investigated and, at the same time, most important allochthonous conifer species in Europe (John, 1988; Linhart, 1990; Kleinshmit, Bestien, 1992; Schober, 1963). According to the available data, cultures of this species have been established in 26 European countries, on the surface area of 200,000 ha (Schober R.). The process of introduction Douglas fir in Europe was initiated in 1850, when first cultures were established. The success and productivity of the first established cultures differed, largely due to the unknown origin of the seeds used for production of seedlings for their establishment. Based on the studies conducted in North America as well as potential tests of this species in Europe, a detailed knowledge of the genetic potential of Douglas-fir provenances was acquired. The obtained results from the comparative tests had an impact on regionalisation and more proper selection of the seed sources in North America, which contributed to stability and overall quality of Douglas-fir cultures in forest sites outside its natural areal. The introduction of Douglas fir in the region of South-east Balkans began towards the end of $19^{\text {th }}$ and at the beginning of $20^{\text {th }}$ century. Initially, it was planted as a park-decorative species, and later as a species in forest cultures. (Kitić-Vrcelj, 1982). Two Douglas-fir provenance trials were established in Serbia in 1982, with the seed from the known North America seed sources, ranging from New Mexico to British Columbia. Trial facilities were created in Juhor near Jagodina and Tanda near Bor from the seedlings produced in the seedling nursery of the Institute of Forestry in Belgrade.

The results of the research conducted in the experimental facilities in Serbia, (Lavadinović, V. et al., 1995, 1996, 1997, 1999, 2001) proved that provenances from the higher latitudes of North America are characterised by genetic potential that makes them suitable for establishing their cultures in Serbia. The above-stated results directed the further research towards Douglas-fir provenances from Canada, of the latitude ranging from $49^{\circ} 10^{\prime}$ to $51^{\circ} 35^{\prime}$, longitude from $115^{\circ} 20^{\prime}$ to $120^{\circ} 10^{\prime}$ and altitude from 488 to $1070 \mathrm{~m}$.

\section{Material and work method}

The paper presents the results of the seedling mean height measurement and their discrepancies, depending on geographic characteristics of the seed origin, in a plant juvenile development phase at the seedling nursery in Sremčica. The seed of 14 Douglas-fir provenances, originating from its natural areal in Canada and obtained through a forest seed centre „Canadian Forest Service” from British Columbia, was used for the production of seedlings for establishment of the trial. The seeds were sown in May 1999, while the trial was established in April 2002, at the seedling nursery in Sremčica. The planting was conducted in rows, one provenance in one row. The distance between the rows was $2 \mathrm{~m}$, while the distance between seedlings in a row was $1 \mathrm{~m}$. Figure 1 presents the spatial layout of provenance origins, while their geographic characteristics and original codes are presented in Table 1.

In October 2010, heights of all trial trees were measured by an altimeter VERTEX III, with the accuracy of 0.1 $\mathrm{mm}$. The obtained data were processed by a computer programme STATGRAPHICS Plus. Statistical justification of differences between height arithmetic means was established by the Duncan test, with the probability of $95 \%$. The impact of provenances' geographic origin on seedling height is determined by the Pierce linear correlation coefficient. 
$130^{\circ} 129$ 128 127126125124123122121120119118117 116 115114113

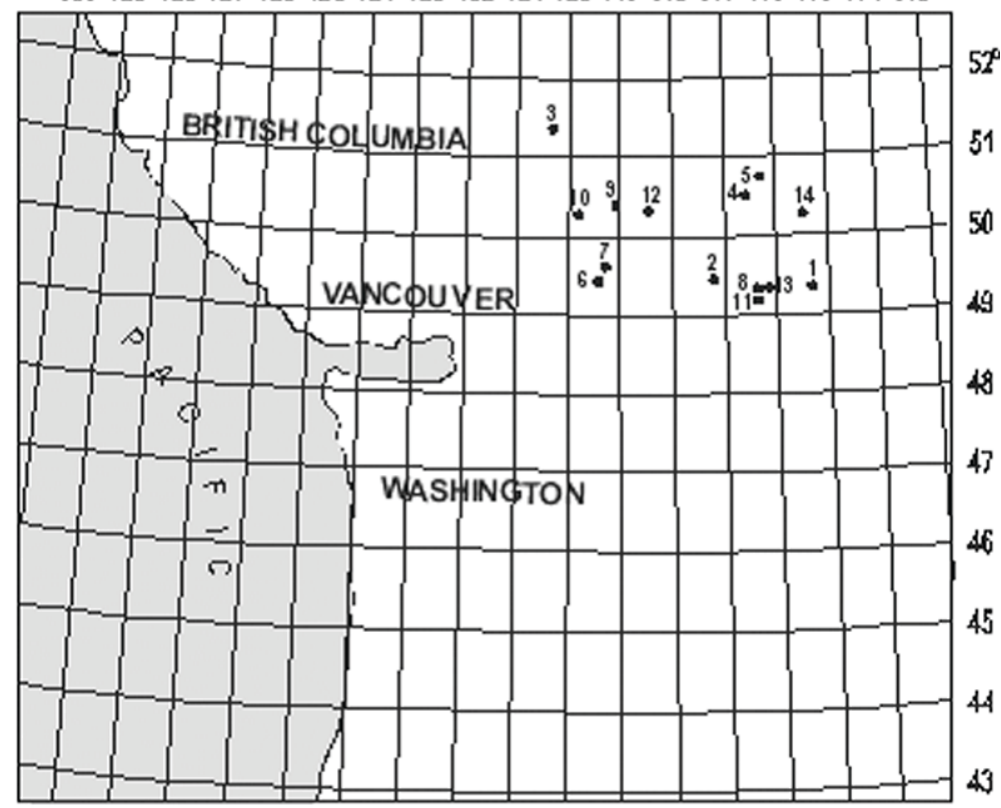

\section{$\begin{array}{lllllll}1-105 \mathrm{~m} & 2 \cdot 871 \mathrm{~m} & 3 \cdot 300 \mathrm{~m} & 1-107 \mathrm{C} & 5-975 \mathrm{~m} & 6 \cdot 884 \mathrm{~m} & 7 \cdot 1035 \mathrm{~m}\end{array}$} $\begin{array}{llllll}8.793 \mathrm{~m} \quad 9.183 \mathrm{~m} \quad 10.701 \mathrm{~m} & 11.1003 \mathrm{~m} \quad 12.900 \mathrm{~m} & 13.933 \mathrm{~m} & 14.1000 \mathrm{~m}\end{array}$

Fig. 1. Spatial layout chart of investigated provenances.

$\mathrm{T}$ a b l e 1. Geographic characteristics of tested provenances.

\begin{tabular}{|c|c|c|c|c|c|}
\hline \multicolumn{2}{|c|}{ Provenance } & \multirow[t]{2}{*}{ Location } & \multicolumn{2}{|c|}{ Geographic } & \multirow{2}{*}{$\begin{array}{c}\text { Altitude } \\
\text { (m) }\end{array}$} \\
\hline No. & Code & & Latitude & Longitude & \\
\hline 1. & 03333 & Cranbrook & $49^{\circ} 25^{\prime}$ & $115^{\circ} 20^{\prime}$ & 1050 \\
\hline 2. & 00848 & Inonoaklin & $49^{\circ} 50^{c}$ & $118^{\circ} 10^{c}$ & 671 \\
\hline 3. & 30667 & Mann Creek & $51^{\circ} 35^{\circ}$ & $120^{\circ} 10^{\circ}$ & 600 \\
\hline 4. & 05227 & Gavia Lake & $50^{\circ} 56^{\circ}$ & $116^{\circ} 35^{\circ}$ & 1070 \\
\hline 5. & 05226 & Nine Bay & $50^{\circ} 58^{\prime}$ & $115^{\circ} 32^{\prime}$ & 975 \\
\hline 6. & 03356 & Trout $\mathrm{Cr}$ & $49^{\circ} 40^{\circ}$ & $119^{\circ} 52^{\prime}$ & 884 \\
\hline 7. & 03360 & Michell Cr & $49^{\circ} 54^{\prime}$ & $119^{\circ} 37^{\circ}$ & 1035 \\
\hline 8. & 01198 & Salmo & $49^{\circ} 15^{c}$ & $117^{\circ} 30^{\circ}$ & 793 \\
\hline 9. & 30460 & Mara Lk & $50^{\circ} 48^{c}$ & $119^{\circ} 00^{\circ}$ & 488 \\
\hline 10. & 00278 & Monte Crk & $50^{\circ} 37^{\circ}$ & $119^{\circ} 52^{\prime}$ & 701 \\
\hline 11. & 03383 & Sheep Creek & $49^{\circ} 10^{c}$ & $117^{\circ} 15^{c}$ & 1000 \\
\hline 12. & 30461 & Cooke Creek & $50^{\circ} 38^{\circ}$ & $118^{\circ} 49^{\prime}$ & 900 \\
\hline 13. & 03389 & Benton Creek & $49^{\circ} 12^{\prime}$ & $117^{\circ} 25^{c}$ & 933 \\
\hline 14. & 05092 & Sun Creek & $50^{\circ} 08^{\prime}$ & $115^{\circ} 52^{\prime}$ & 1000 \\
\hline
\end{tabular}




\section{Results and discussion}

A comparative analysis of the attained mean heights of Douglas-fir seedlings from 14 Canadian provenances was published for the purpose of establishing inter-provenance variability and its dependence on geographic characteristics of the seed origin.

T a b l e 2. Mean heights of tested Douglas-fir provenances.

\begin{tabular}{|c|c|c|c|c|c|}
\hline \multicolumn{2}{|c|}{ Provenance } & \multirow{2}{*}{$\begin{array}{c}\text { Height } \\
(\mathbf{c m})\end{array}$} & Provenance & \multirow{2}{*}{\begin{tabular}{c} 
Height \\
\cline { 5 - 6 }$(\mathbf{c m})$
\end{tabular}} \\
\hline No. & Code & No. & Code & 146.5 \\
\hline 1. & 03333 & 188.4 & 8. & 01198 & 282.7 \\
\hline 2. & 00848 & 312.9 & 9. & 30460 & 193.4 \\
\hline 3. & 30667 & 271.9 & 10. & 00278 & 222.4 \\
\hline 4. & 05227 & 217.5 & 11. & 03383 & 294.8 \\
\hline 5. & 05226 & 182.2 & 12. & 30461 & 217.2 \\
\hline 6. & 03356 & 149.4 & 13. & 03389 & 175.0 \\
\hline 7. & 03360 & 158.1 & 14. & 05092 & \\
\hline
\end{tabular}

T a b l e 3. Analysis of variance.

\begin{tabular}{|l|c|c|c|c|c|}
\hline & Sum of squares & df & Mean square & F & Sig. \\
\hline Between groups & 1597347.199 & 13 & 122872.861 & 36.941 & 0.000 \\
\hline Within groups & 1769540.230 & 532 & 3326.203 & & \\
\hline Total & 3366887.429 & 545 & & & \\
\hline
\end{tabular}

$\mathrm{T}$ a b le 4. Duncan test for the height of 14 Douglas-fir provenances

\begin{tabular}{|c|c|c|c|c|c|c|c|c|}
\hline \multirow[t]{2}{*}{ Provenance } & \multirow[t]{2}{*}{$\mathbf{N}$} & \multicolumn{7}{|c|}{ Subset for alpha $=\mathbf{0 . 0 5}$} \\
\hline & & 1 & 2 & 3 & 4 & 5 & 6 & 7 \\
\hline 8 & 17 & 146.471 & & & & & & \\
\hline 6 & 28 & 149.393 & & & & & & \\
\hline 7 & 64 & 158.078 & 158.078 & & & & & \\
\hline 14 & 31 & 174.968 & 174.968 & 174.968 & & & & \\
\hline 5 & 53 & & 182.208 & 182.208 & & & & \\
\hline 1 & 31 & & & 188.355 & 188.355 & & & \\
\hline 10 & 49 & & & 193.429 & 193.429 & 193.429 & & \\
\hline 13 & 47 & & & & 217.191 & 217.191 & & \\
\hline 4 & 39 & & & & 217.513 & 217.513 & & \\
\hline 11 & 29 & & & & & 222.379 & & \\
\hline 3 & 29 & & & & & & 271.897 & \\
\hline 9 & 35 & & & & & & 282.686 & \\
\hline 12 & 36 & & & & & & 294.833 & 294.833 \\
\hline 2 & 58 & & & & & & & 312.948 \\
\hline Sig. & & 0.060 & 0.100 & 0.229 & 0.054 & 0.055 & 0.119 & 0.191 \\
\hline
\end{tabular}


The largest mean height of $312.9 \mathrm{~cm}$ was attained by the trees of the second provenance (00848), followed by the twelfth with $294.8 \mathrm{~cm}$ (30461), while the smallest height of $146.5 \mathrm{~cm}$ was attained by the trees of the eighth provenance (01198), the sixth $149.4 \mathrm{~cm}$ (03356), the seventh $158.1 \mathrm{~cm}$ (03360) and the fourteenth $175.0 \mathrm{~cm}$ (05092), as can be seen in Table 2.

The obtained statistical data point out to the existence of genetic variability in selected Douglas-fir provenances, understanding of which is essential for the further success of introduction work.

The results of the variance analysis (Table 3 ) indicate the existence of statistically significant discrepancies at the level $\mathrm{p}<0.05$, between mean height of 14 Douglas-fir provenance trees.

By means of the Duncan test, statistically significant differences between mean heights of Douglas-fir provenances were determined at the reliability level $\mathrm{p}<0.05$ (Table 4 ). The provenances were grouped into seven homogenous groups, which confirmed the variations in mean heights of 14 Douglas-fir provenances. The provenances 2 and 12 belong to a homogenous group with the largest mean heights whereas the provenances $8,6,7$ and 14 belong to a group with the smallest mean heights.

The impact of provenances' geographic origin on a Douglas-fir seedling height was examined by means of the Pierce linear correlation coefficient.

$\mathrm{T}$ a b le 5. Geographic location and mean height correlation matrix of 14 Douglas-fir provenances.

\begin{tabular}{|l|c|c|c|c|}
\hline & Latitude & Longitude & Altitude & Height \\
\hline Latitude & 1.00 & 0.2897 & -0.3803 & 0.3845 \\
\hline Longitude & & 1.00 & $-0.6337^{\star}$ & 0.2538 \\
\hline Altitude & & & 1.00 & $-0.5384^{*}$ \\
\hline Height & & & & 1.00 \\
\hline
\end{tabular}

${ }^{*}$ Significant for $\mathrm{p}<0.05$.

On the basis of the Pierce coefficient values (Table 5), it can be concluded that there is a positive correlation between latitude and seedling height, but that correlation is not statistically significant. There is a positive correlation between longitude and seedling height as well, but that correlation is also not statistically significant. There is a negative correlation between altitude and seedling mean height, and that correlation is statistically significant. A similar correlation was also found in the tests involving seeds of the same provenances (Lavadinović V. et al., 2004) as well as in the tests involving the mean diameter (Popović V., Lavadinović V., 2011).

Based on the obtained results, it can be concluded that the size of the seedling height is increasing from east provenances to the west and from south provenances to the north. The size of the seedling height is decreasing with the increase of altitude, which is the most pronounced impact (Fig. 2).

\section{Conclusion}

In the juvenile development phase in seedling nursery conditions, the plants exhibit variations in growth characteristics. In order to draw more certain conclusions with respect to 

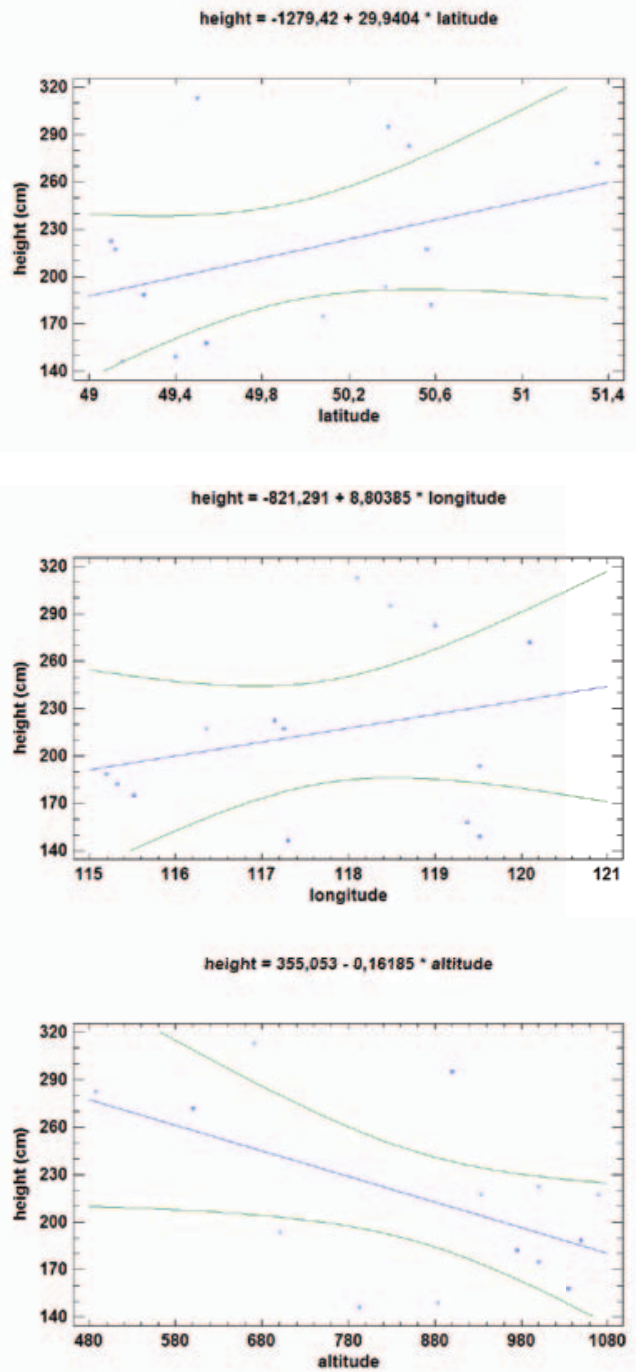

Fig. 2. Latitude, longitude and altitude impact on the seedling height.

which provenance exhibits better adaptability, it is necessary to monitor the development of older trees.

In this phase of juvenile plant development, the provenances 2, 12, 9 and 3 stood out as the best according to the attained mean heights, while the provenances $8,6,7$ and 14 were ranked the worst. However, it is too early to propose those data as the underlying basis for the establishment of Douglas-fir cultures. The conducted research presents the basis for selection of a relevant Douglas-fir Canadian provenance for establishment of plantations in Serbia. In 
order to conduct a more proper selection of provenances, it is necessary to continue to monitor the plant development and then, by consolidating several research results, recommend provenances that are most suitable for the establishment of Douglas-fir cultures in Serbia.

\section{Acknowledgements}

This paper was produced in the framework of the project 'Study of climatic change environment impact: monitoring impact, adaptation and mitigation' (43007), financed by the Republic of Serbia Ministry of Education and Science, in the framework of Integrated and Inter-disciplinary research programme for the period 2011-2014.

\section{References}

Bradley, J., Clair, St. \& Sviezko R.A. (1999). Genetic variation in response to shade in coastal Douglas-fir. Canada Journal of Forest Research, 29, 1751-1763.

John, S.E.T. (1988). Early genotype by environment interaction and genetic variance of Douglas-fir. Ph. D. disertation, North Carolina State University, Raleigh.

Kitić-Vrcelj, D. (1982). Kulture duglazije Pseudotsuga menziensii (Mirb.) Franco u različitim staništima SR Srbije. Beograd: Institut za šumarstvo i drvnu industriju.

Kleinschmit, J. \& Bastien J.CH. (1992). IUFRO's Role in Douglas-Fir Tree Improvement. Silva Genetica, 41, 3, 161172.

Lavadinović, V. (1995): Promenljivost 29 provenijencija duglazije (Pseudotsuga taxifolia Britt.) u test kulturama Srbije u cilju unapređenja introdukcije ove vrste. Magistarski rad (rukopis) (pp. 32-143). Beograd: Šumarski fakultet.

Lavadinović, V. (1996): Zavisnost visine dvogodišnjih biljaka duglazije (Pseudotsuga taxifolia Britt.) različitih provenijencija od geografskih karakteristika. Zbornik radova. Institut za Šumarstvo, 40-41, 137-145.

Lavadinović, V., Isajev, V. \& Koprivica M. (1996a). Efect of seed germination on survival and height of two-year old Douglas-fir of different provenances. Genetica, 28, 2, 103-114.

Lavadinović, V. \& Koprivica M. (1996b). Dependence of Young Douglas-fir stands of different provenances on beech sites in Serbia. Proceedings from the IUFRO Conference (pp. 390-400). Copenhagen.

Lavadinović, V., Koprivica, M. \& Marković N. (1996c). Comparison of diameter and height of twenty Douglas fir (Pseudotsuga taxifolia Britt.). Proceedings of the Scientific Papers, Second Balkan Scientific Conference on Study, Conservation and Utilisation of Forest Resources. Sofia, Bulgaria: 196-200.

Lavadinović, V. \& Koprivica M. (1997). Development of Young Douglas-fir stands of different provenances on oak site in Serbia. Proceedings from the IUFRO Conference (pp. 231-242).

Oeiras, Portugal

Lavadinović, V. \& Koprivica M. (1999). Development of young Douglas - fir stands of different provenances on oak site in Serbia. Novas Tecnologias, Editado por Ana Amaro \& Margarida Tome. Empirical and Process-Based Models for Forest Tree and Stand Growth Simulation (pp. 231-241). LDA Lisboa: Edicoes Salamandra.

Lavadinović, V., Koprivica, M. \& Isajev V. (2001). Dependence of Douglas-fir height increment on geographic characteristics of provenance in central Serbia. Abstracts, "Tree Rings and People", International Conference on the Future of Dendrochronology (p. 158). Davos, Switzerland.

Lavadinović, V., Isajev, V. \& Ivetić V. (2004). Promenljivost klijavosti i energije klijanja duglazije kanadske provenijencije. Glasnik Šumarskog fakulteta Univerziteta u Banjoj Luci (pp. 87-99).

Linhart, Y.B. \& Davis M.L. (1990). The importance of local genetics variability in Douglas-fir. Interior Douglas-fir management Symposium proceedings (pp. 63-72). Spokane, Washington.

Schober, R. (1963). Experiances with the Douglas-fir in Europe. World Consult. for Genet. and Tree Improv., Stockholm. FAO/FORGEN, 63, 4/5, 18. 